3. Maroeska Te Loo D, Bosma N, Van Hinsbergh V, Span P, De Waal R, Clarijs R, Sweep C, Monnens L, Van Den Heuvel L. Elevated levels of vascular endothelial growth factor in serum of patients with D+ HUS. Pediatr Nephrol 2004;19:754-760.

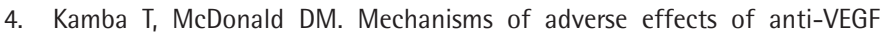
therapy for cancer. Br J Cancer 2007;96:1788-1795.

5. Bollée G, Patey N, Cazajous G, Robert C, Goujon JM, Fakhouri F, Bruneval $P$, Noël LH, Knebelmann B. Thrombotic microangiopathy secondary to VEGF pathway inhibition by sunitinib. Nephrol Dial Transplant 2009;24:682-685.

6. Costero O, Picazo ML, Zamora P, Romero S, Martinez-Ara J, Selgas R. Inhibition of tyrosine kinases by sunitinib associated with focal segmental glomerulosclerosis lesion in addition to thrombotic microangiopathy. Nephrol Dial Transplant 2010;25:1001.
7. Noronha V, Punatar S, Joshi A, Desphande RV, Prabhash K. Sunitinibinduced thrombotic microangiopathy. J Cancer Res Ther 2016;12:6-11.

8. Kapiteijn E, Brand A, Kroep J, Gelderblom H. Sunitinib induced hypertension, thrombotic microangiopathy and reversible posterior leukencephalopathy syndrome. Ann Oncol 2007;18:1745-1747.

9. Jha PK, Vankalakunti M, Siddini V, Bonu R, Prakash GK, Babu K, Ballal HS Sunitinib induced nephrotic syndrome and thrombotic microangiopathy. Indian J Nephrol 2013;23:67-70.

10. Choi MK, Hong JY, Jang JH, Lim HY. TTP-HUS associated with sunitinib. Cancer Res Treat 2008;40:211-215.

\title{
Kimura Disease Associated with Minimal Change Disease
}

\author{
Minimal Değişiklik Hastalığı ile Illişkili Kimura Hastalığı
}

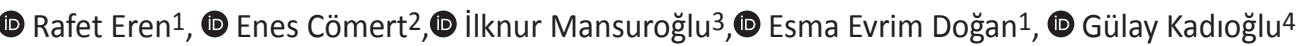

1 University of Health Sciences Turkey, Prof. Dr. Cemil Taşcıoğlu City Hospital, Department of Hematology, Istanbul, Turkey

2 University of Health Sciences Turkey, Prof. Dr. Cemil Taşcıoğlu City Hospital, Department of Internal Medicine, Istanbul, Turkey

3 University of Health Sciences Turkey, Prof. Dr. Cemil Taşcıoğlu City Hospital, Department of Pathology, istanbul, Turkey

«University of Health Sciences Turkey, Prof. Dr. Cemil Taşcıoğlu City Hospital, Department of Nephrology, Istanbul, Turkey

\section{To the Editor,}

Kimura disease is a benign chronic inflammatory disease with unknown etiology, which usually presents with lymphadenopathies in the head and neck, peripheral blood eosinophilia, and elevated serum immunoglobulin E ( $\mathrm{lgE}$ ) levels. It is mostly observed in young males of Asian descent in the second and third decades of life, but sporadic cases in other ethnic groups have also been reported [1,2]. Here we present a patient with Kimura disease and concomitant nephrotic syndrome who presented with lymphadenopathies of atypical locations.

A 25-year-old male patient presented with new-onset hypertension, decreased urine output, and lower extremity swelling. His past medical history was unremarkable with no history of allergies. On examination, his blood pressure was $140 / 100 \mathrm{mmHg}$, heart rate was $90 / \mathrm{min}$, and body temperature was $37^{\circ} \mathrm{C}$. He had bilateral $2+$ pitting edema of the bilateral lower extremities and an enlarged, soft, nontender $3-\mathrm{cm}$ left inguinal lymph node. Laboratory evaluation results were as follows: white blood cells, 6790/ $\mu \mathrm{L}_{\text {; }}$ eosinophils,

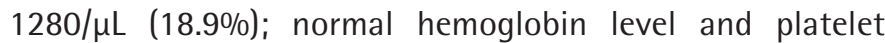
count; serum creatinine, $0.66 \mathrm{mg} / \mathrm{dL}$; urea, $26 \mathrm{mg} / \mathrm{dL}$; albumin, $2.4 \mathrm{~g} / \mathrm{dL}$; triglyceride, $295 \mathrm{mg} / \mathrm{dL}$; erythrocytesedimentation rate, $81 \mathrm{~mm} / \mathrm{h}$; total $\lg \mathrm{E}_{1} 3318 \mathrm{kU} / \mathrm{L}(<87)$. Urinalysis showed $3+$ protein and the spot urine protein/creatinine ratio was $7819 \mathrm{mg} / \mathrm{g}$. Viral serologies and rheumatologic markers were negative. Serum C3, C4, IgG, IgA, and IgM levels were also normal. A percutaneous renal biopsy was performed for nephrotic syndrome. Pathological examination of the specimen revealed no significant changes by light microscopy and was negative for immunofluorescence, indicating minimal change disease. The patient was started on low-dose perindopril with a gradual increase to $10 \mathrm{mg} /$ day. Positron emission tomography-computed tomography (CT) performed to assess any associated malignancy showed hypermetabolic activity in the inguinal and right external iliac regions (SUV ${ }_{\text {max }}$ : 2.5). The left inguinal lymph node was excised. The pathology was reported to be consistent with Kimura disease (Figure 1). During follow-up, his creatinine levels progressively increased to $2 \mathrm{mg} / \mathrm{dL}$ and he was started on methylprednisolone at $1 \mathrm{mg} / \mathrm{kg}$. At week 1 , his creatinine regressed to baseline. At week 3 , complete remission of proteinuria was achieved and 

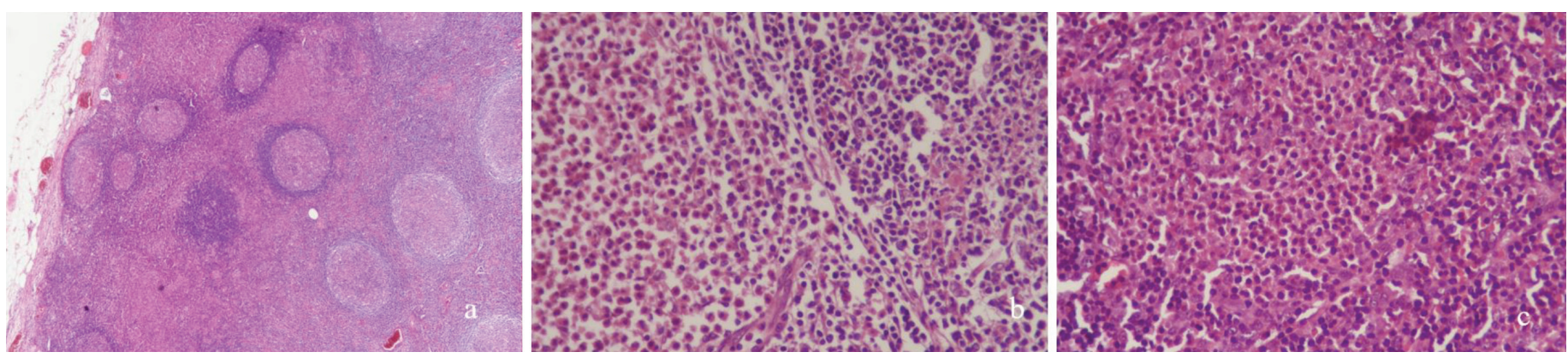

Figure 1. Lymph node biopsy: (a) markedly hyperplastic follicles with reactive germinal centers, (b) well-defined peripheral mantle zone, and (c) intense diffuse eosinophilia with formation of eosinophilic microabscesses. Paracortical plasma cells were also present. IgG4 was increased with a value of $0.8 \%$, which was below the $40 \%$ threshold for lgG4-related disease.

the steroid was tapered slowly. Abdominal CT performed in the fourth month showed significant decrease in the number and size of lymph nodes. Steroid treatment was discontinued at the seventh month. To date, the patient has no symptoms and is being followed recurrence-free.

There are many reports of renal involvement in Kimura disease. A review of 175 patients with Kimura disease found renal involvement in 12\% [3]. Renal biopsies of patients with renal involvement of Kimura disease showed mesangioproliferative glomerulonephritis, minimal change disease, focal segmental glomerulosclerosis, membranous nephropathy, membranoproliferative glomerulonephritis, and acute tubular necrosis [4]. The treatment, however, remains unclear. While excision is considered adequate in patients without renal involvement, systemic steroids are recommended in patients who have renal involvement or relapse after excision [5].

Here, we have presented a patient who was diagnosed with minimal change disease and Kimura disease and responded to steroid treatment. Kimura disease should be considered in patients investigated for lymphadenopathies in the presence of elevated serum IgE levels and renal disease.

Keywords: Kimura disease, Lymphadenopathy, Eosinophilia, Minimal change disease

Anahtar Sözcükler: Kimura hastalığı, Lenfadenopati, Eozinofili, Minimal değişiklik hastalığı

\section{Ethics}

Informed Consent: The patient provided informed consent for this publication.

\section{Authorship Contributions}

Surgical and Medical Practices: R.E., E.C., G.K.; Concept: E.E.D.; Design: R.E., I.M.; Data Collection or Processing: E.C., E.E.D.; Analysis or Interpretation: R.E., I.M.; Literature Search: R.E., G.K.; Writing: R.E., G.K.

Conflict of Interest: No conflict of interest was declared by the authors.

Financial Disclosure: The authors declared that this study received no financial support.

\section{References}

1. Kumar V, Mittal N, Huang Y, Balderracchi J, Zheng HX, Li Z, Xu Y. A case series of Kimura's disease: a diagnostic challenge. Ther Adv Hematol 2018;9:207211.

2. Yu B, Xu G, Liu X, Yin W, Chen H, Sun B. Kimura's disease affecting multiple body parts in a 57-year-old female patient: a case report. Allergy Asthma Clin Immunol 2019;15:84.

3. Yamada A, Mitsuhashi K, Miyakawa Y, Kosaka K, Takehara K, lijima M, Tanaka K, Shibata S. Membranous glomerulonephritis associated with eosinophilic lymphfolliculosis of the skin (Kimura's disease): report of a case and review of the literature. Clin Nephrol 1982;18:211-215.

4. Chen Y, Wang J, Xu F, Zeng C, Liu Z. Clinicopathological features and prognosis of Kimura's disease with renal involvement in Chinese patients. Clin Nephrol 2016;85:332-339.

5. Su S, Chen X, Li J, Yu J, Zhang L. Kimura's disease with membranoproliferative glomerulonephritis: a case report with literature review. Ren Fail 2019;41:126-130. 